\title{
Identification of an EF-Tu protein that is periplasm-associated and processed in Neisseria gonorrhoeae
}

\author{
Stephen F. Porcella, ${ }^{1}$ R. J. Belland ${ }^{2}$ and R. C. Judd ${ }^{3}$ \\ Author for correspondence: Stephen F. Porcella. Tel: +1 214648 5980. Fax: +1 2146485907. \\ e-mail : porcella@utsw.swmed.edu
}

1 Department of Microbiology, University of Texas Southwestern Medical School at Dallas, Dallas, Texas 75235, USA

2 Rocky Mountain Laboratories, NIAID, NIH, Hamilton, Montana 59840, USA

3 Division of Biological Sciences, University of Montana, Missoula, Montana 59812, USA
A 44 kDa protein is a dominant component of periplasmic extracts of Neisseria gonorrhoeae. Peptide sequence generated from a cyanogen-bromide-cleaved fragment of this protein indicated sequence homology with elongation factorTU (EF-Tu). Polyclonal antiserum was made against the $\mathbf{4 4} \mathrm{kDa}$ protein purified from periplasm extracts of $\boldsymbol{N}$. gonorrhoeae. The preabsorbed antiserum was immunoblotted against whole-cell lysates on two-dimensional gels. A 44 kDa protein and a smaller $37 \mathrm{kDa}$ protein were recognized by this antiserum. A $N$. gonorrhoeae $\lambda$ phage DNA library was screened and a clone expressing a 44 kDa protein was identified. The DNA insert in this clone contained several genes homologous to genes contained in the str operon of Escherichia coli. One ORF product with a calculated molecular mass of $43 \mathrm{kDa}$ was highly homologous to the EF-TUA of E. coli. A synthetic peptide antiserum specific for a portion of the $\mathrm{C}$ terminus of EF-Tu confirmed that the $37 \mathrm{kDa}$ protein in whole-cell lysates of $\boldsymbol{N}$. gonorrhoeae was a processed form of EF-Tu. Deletion of the tufA gene homologue in $\boldsymbol{N}$. gonorrhoeae was attempted but was unsuccessful.

Keywords: Neisseria gonorrboea, tuf $A, \mathrm{EF}-\mathrm{Tu}$, processing

\section{INTRODUCTION}

Elongation factor-Tu (EF-Tu) is a ubiquitous protein involved in protein synthesis and may compose $10 \%$ of the total cellular protein of a rapidly dividing Eschericbia coli bacterium (Van der Meide et al., 1982). EF-Tu has also been described as the dominant protein released in periplasmic extracts of E. coli (Jacobson et al., 1976). In Gram-negative bacteria, EF-Tu is typically encoded by two almost identical genes, $\operatorname{tuf} A$ and $t u f B$. Therefore, EF$\mathrm{Tu}$ is a generic term which may be applicable to either EFTuA, EF-TuB, or both. These tuf genes have been identified and well characterized in E. coli and they differ in only one amino acid (Arai et al., 1980; Jones et al., 1980). During conditions of nutrient limitation, EF-Tu appears to be methylated and cytoplasmically membrane bound (Young \& Bernlohr, 1991; Young et al., 1990). Southern analysis has demonstrated that the gonococcus (Neisseria gonorrboeae) has two tuf genes (Goldstein et al.,

The GenBank accession number for the sequence reported in this paper is L36380.
1989); a situation similar to that in E. coli (Jaskunas et al., 1975) and Salmonella typhimurium (Hughes, 1990).

The $41-45 \mathrm{kDa}$ proteins of $N$. gonorrboeat have had numerous characteristics described for them (Chen $e t$ al., 1984; Hill \& Judd, 1988, 1989; Judd et al., 1991; Shafer, 1988; Shafer \& Judd, 1991; Shafer \& Morse, 1987; Swanson, 1981; Zak et al., 1984). Two closely migrating $44 \mathrm{kDa}$ proteins have been found in periplasm and nonperiplasm fractions of $N$. gonorrboeae (Judd \& Porcella, 1993; Porcella \& Judd, 1993). In an effort to determine which $44 \mathrm{kDa}$ proteins are responsible for the observed characteristics, we purified a $44 \mathrm{kDa}$ protein from the periplasm of $N$. gonorrboeae. This protein was cleaved with cyanogen bromide $(\mathrm{CNBr})$ and a peptide fragment was sequenced and found to be highly homologous to EF-Tu (Judd \& Porcella, 1993).

In this report we describe the further purification of this periplasm-associated $44 \mathrm{kDa}$ protein and the production of polyclonal antibodies. This antiserum, designated $44 \mathrm{kDa}$ periplasmic antiserum, was preabsorbed with $E$. coli lysates and immunoblotted against whole-cell lysates of $N$. gonorrboeae. Reactivity of the antisera to a $44 \mathrm{kDa}$ 
protein and a smaller $37 \mathrm{kDa}$ protein implied that the antiserum was sufficiently specific. A gonococcal library was immunoblotted with the polyclonal antiserum and a clone was identified which constitutively produced only one $44 \mathrm{kDa}$ protein. Sequence analysis of the $N$. gonorrboeae DNA within this clone indicated that it contained several str operon-like genes, including a single ORF with a predicted product of molecular mass $44 \mathrm{kDa}$ that was highly homologous to EF-TuA.

EF-Tu has recently been shown to be a primary target in a phage exclusion mechanism where the majority of the molecule is cleaved at a highly conserved site producing a 37 kDa protein (Yu \& Snyder, 1994). We used a synthetic, EF-Tu-specific, peptide antiserum previously described (Judd \& Porcella, 1993), to probe N. gonorrboeae wholecell lysates in two-dimensional gels. We found that both the $44 \mathrm{kDa}$ protein and the smaller $37 \mathrm{kDa}$ protein reacted with the antiserum. These results indicate that the $37 \mathrm{kDa}$ protein in $N$. gonorrhoeae is a processed form of EF-Tu.

Analysis of the function of EF-TuA and B in E. coli and S. typbimurium has indicated that EF-TuA is essential for E. coli (Vijgenboom \& Bosch, 1987) but not essential for S. typhimurium (Hughes, 1990). We attempted to delete the N. gonorrboeat tuf $A$ gene via homologous recombination with a selectable, transposon-inactivated gonococcal tuf $A$. All mutants obtained were heterodiploid in that they contained an intact genomic copy of tuf $A$ along with the transposon-inactivated gene in an unknown genomic location.

\section{METHODS}

Bacteria. These included N. gonorrboeae strains MS11 (courtesy of John Swanson, Rocky Mountain Laboratory, Hamilton, MT) and FA19 (courtesy of William Shafer, Dept of Microbiology and Immunology, Emory University School of Medicine, Atlanta, GA). E. coli XL1 was obtained from Stratagene.

Transparent, non-piliated gonococci were grown at $37^{\circ} \mathrm{C}$ on clear typing medium as previously described (Swanson, 1982). Cells were passaged daily and large transparent colonies were selected. Cells were harvested at $18 \mathrm{~h}$ and washed twice in Dulbecco's PBS (DPBS).

Protein purification. Protocols for whole-cell lysates have been previously described by Judd (1982). Periplasmic fractions of N. gonorrboeae were isolated as previously described (Judd \& Porcella, 1993). Five hundred microlitres of solubilized FA19 periplasmic extract was layered onto $9 \%(v / v)$ SDS-PAGE preparative gels and electrophoresed. Gels were stained and the $44 \mathrm{kDa}$ protein was excised from gels and purified for antibody production following the methods described by Judd (1988). Protein was quantified using Bio-Rad's BCA kit.

Preparation of antisera. Monospecific, polyclonal rabbit antiserum was generated against a $N$. gonorrboede strain FA19 periplasm-associated $44-\mathrm{kDa}$ protein following standardized immunological protocols (Judd, 1991). Preabsorption of the antiserum was performed by first growing E. coli strain XL1Blue (Stratagene) overnight in $100 \mathrm{ml}$ Luria-Bertani (LB) medium. Cells were harvested by centrifugation at $5000 \mathrm{~g}$ fot $10 \mathrm{~min}$ at $4{ }^{\circ} \mathrm{C}$ and resuspended in $3 \mathrm{ml} 50 \mathrm{mM}$ Tris $/ \mathrm{HCl}$ $(\mathrm{pH} 8.0), 10 \mathrm{mM}$ EDTA ( $\mathrm{pH} \mathrm{8.0)}$. The suspension was frozen and thawed three times and sonicated at fuli power for six periods of $20 \mathrm{~s}$ at $4^{\circ} \mathrm{C}$. DNAse (Sigma) was added to the homogenate to a final concentration of 1 unit $\mathrm{ml}^{-1}$ and centrifuged at $12000 \mathrm{~g}$ for $10 \mathrm{~min}$ at $4{ }^{\circ} \mathrm{C}$. The supernatant was absorbed onto nitrocellulose paper, dried, and subsequently incubated at 10 min intervals in the $44 \mathrm{kDa}$ periplasmic anti. serum. The filters were developed according to standard chromogenic Western blot procedures (Maniatis et al, 1982). All E. coli cross-reactive antibodies were presumed to be temoved from the antisera when nitrocellulose filters no longer showed any reactivity during Western blot development.

Polyclonal antibodies were prepared against a multiple antigenic peptide containing the sequence FRKLLDEGQA as previously described (Judd \& Porcella, 1993)

Cloning and DNA sequence analysis. $A N$. gonorrboeae library, generated by partial digestion of MS11 genomic DNA with the restriction enzyme EcoRI and subsequent ligation into the EcoRI site in the Jambda Zap II vector (Stratagene), was screened with the $44 \mathrm{kDa}$ periplasmic antiserum following the manufacturer's protocol (Stratagene). Positive clones were plaque purified and rescued as described in the Stratagene protocol. Plasmid DNAs were isolated and purified for sequencing using the Qiagen Midi prep kit (Qiagen). Sequencing of the cloned DNA inserts was performed using forward and reverse primers (Stratagene) and synthetic oligonucleotides made using an ABI oligonucleotide synthesizer at the Murdoch Molecular Biology Facility at the University of Montana and at Rocky Mountain Labotatories in Hamilton. Sequencing reactions were performed using the dideoxynucleotide chain-termination method (Sanger et al., 1977). Nucleotide sequencing also was performed using an Applied Biosystems model $373 \AA$ automated DNA sequencer and PRISM ready reaction DyeDeoxy Terminator cycle sequencing kits according to manufacturer's instructions (Applied Biosystems). Nucleotide and deduced amino acid sequences were analysed and manipulated using the University of Wisconsin Computer Genetics Group version 7.3 (GenBank database release 82.0) (Devereux et al., 1984) and MacVector version 4.1.1 (International Biotechnologies-Kodak) software packages. Potential promoter sites within DNA sequences were searched and assigned similarity scores based upon known E. coli promoter sequences using the MACTARGSEARCH algorithm (Multigan et al., 1984).

Gel electrophoresis. SDS-PAGE was performed using the discontinuous buffer system of Laemmli (1970). High-resolution two-dimensional gel electrophoresis was performed as described by O'Farrell (1975) using Bio-Rad's Mini-Protean II 2-D kit.

Shuttle mutagenesis. The shuttle mutagenesis protocol previously described by Seifert et al. was used (Seifert \& So, 1991; Seifert et al., 1986, 1990) to insertionally inactivate the cloned tuf $A$ gene. The $N$. gonorrboea DNA insert in clone 961 was first digested with ClaI and EcoRI and a $1.7 \mathrm{~kb}$ fragment was gel purified. This $1.7 \mathrm{~kb}$ fragment, which contained the entire tuf $A$ gene as well as rpsJ, was cloned into the shuttle mutagenesis vector pHSS6 via ClaI and EcoRI sites and mutagenized following the guidelines previously described (Seifert $e t$ al., 1986, 1990; Seifert \& So, 1991). pHSS6 constructs that contained mutagenized tuf $A$ genes were PCR mapped using primers specific to the DNA $5^{\prime}$ of the tuf $A$ gene $\left(5^{\prime} \mathrm{GT}^{\prime} T G A-\right.$ AGTGGAAACTCCG 3', designated $5^{\prime}$ Tuf) and $3^{\prime}$ (5' AAGCTTTCAGGCGGATAC $3^{\prime}$, designated $3^{\prime}$ Tuf of the $t w A$ gene. Orientation of the chloramphenicol marker respective to the $u$ f A gene was determined using the 5'TufA or 3'TufA primers and a primer specific to the minus strand of the chloramphenicol gene (5' TCACCAGCTCACCGTCTT'TC 3', designated $C$ at). A mutagenized tuf $A$ gene was identified which 
contained the inactivated transposon located within the tuf $A$ gene. The fragment of DNA containing the mutagenized tuf $A$ gene along with the flanking gonococcal sequences was cut from the vector using the restriction enzyme NotI and gel purified. Transformation of N. gonorrboeae was performed with the Not I fragment and chloramphenicol-tesistant mutants were selected following protocols previously described (Goodman \& Scocca, 1991; Seifert \& So, 1991). Long incubation times and close observation of the plates were performed in order to detect cxtremcly slow growing mutants.

PCR and Southern analysis of mutants. PCR was performed using a Perkin-Elmer Cetus Thermocycler and Taq polymerase, under reaction conditions previously described (Sambrook $e t$ al., 1989). PCR products were gel purified for ligation or Southern blot hybridization procedures using the Qiaex DNA purification kit (Qiagen). PCR mapping of the genomic DNA of the chloramphenicol-resistant mutants, wild-type MS11 genomic DNA (negative control), and the transforming DNA (positive control) was performed using the oligonucleotides $5^{\prime}$ Tuf, 3'Tuf and Cat described above. Total genomic DNA was isolated from $N$. gonorrboeae transformation mutants using a DNA extraction kit (Stratagene) following the procedures recommended by the manufacturer.

Southern blotting and hybridization experiments were performed under high-stringency conditions following the protocol previously described (Cohen, 1990). Specific probes were intrinsically labelled using the Boehringer Mannheim random labelling primer kit.

\section{RESULTS AND DISCUSSION}

Two-dimensional isoelectric-focusing SDS-PAGE gels of whole-cell lysates of $N$. gonorrboeae strain MS11 showed that many proteins (about 11) that differ in pI migrate at a molecular mass of $44 \mathrm{kDa}$ (Fig. 1). This same result has been seen for $N$. gonorrboeae strain FA19 (data not shown). The fact that so many proteins can be observed to migrate at this molccular mass may explain why so many diverse functions have been associated with this protein. Immunoblotting of MS11 whole-cell lysates separated by twodimensional gel electrophoresis with the preabsorbed $44 \mathrm{kDa}$ periplasmic antisera showed that two proteins, with calculated molecular masses of $44 \mathrm{kDa}$ and $37 \mathrm{kDa}$, were recognized by the antiserum in Fig. 1. This experiment has been repeated with $N$. gonorrhoeae strain FA19 whole-cell lysates with identical results (data not shown).

The $44 \mathrm{kDa}$ periplasmic antiserum was used to probe a $N$. gonorrboea lambda Zap II genomic library. Four clones were isolated which reacted with the antiserum. Of the four reactive clones, one slow-growing $E$. coli recombinant clone, designated 961, was selected for further analysis. Of the fout clones originally isolated, the 961 clone produced the least amount of $44 \mathrm{kDa}$ protein by immunoblot comparison of the $\lambda$ plaques, yet it was the only clone which did not die after the second passage following rescue. Fig. $2(a, b)$ shows the results of twodimensional gel analysis and immunoblotting of 961 and host cell XI.1 with the $44 \mathrm{kDa}$ periplasmic antiserum. There was minimal cross reactivity with $E$. coli XL1 proteins by the preabsorbed antiserum while a protein from clone 961 with a molecular mass of $44 \mathrm{kDa}$ was observed to react. Interestingly, in Fig. 2(a), a smaller molecular mass protein of approximately $37 \mathrm{kDa}$ was not seen to react with the $44 \mathrm{kDa}$ periplasmic antiserum in clone 961 blots. Based upon the specificity and reactivity of the antiserum, we believe we have cloned the periplasmassociated $44 \mathrm{kDa}$ protein of $N$. gonorrboede (Fig. 1).

Induction of the 961 clone with IPTG did not appreciably alter expression of the $44 \mathrm{kDa}$ protein on one-dimensional SDS-PAGE gels (data not shown). This result suggests

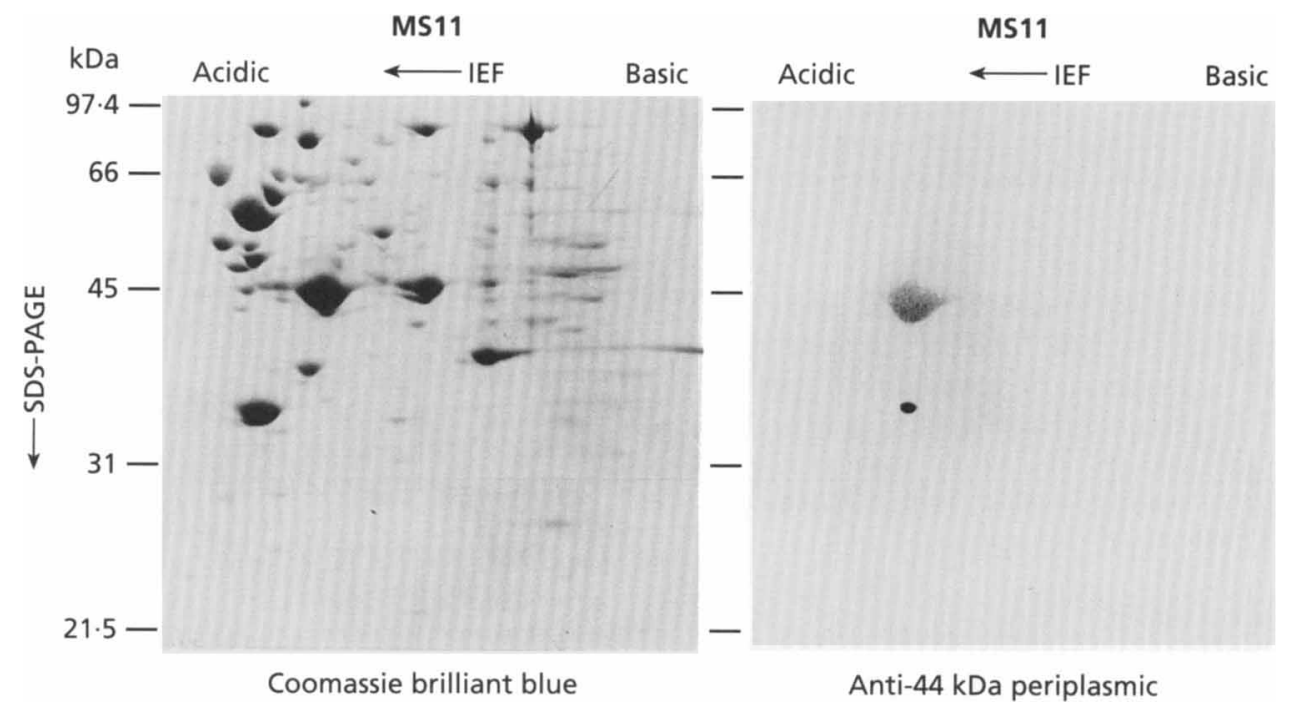

Fig. 1. Two-dimensional gel electrophoretic analysis of $N$. gonorrhoeae strain MS11 probed with 44 kDa periplasmic antiserum. Whole-cell lysates of $N$. gonorrhoeae strain MS11 were stained with Coomassie brilliant blue and probed with $44 \mathrm{kDa}$ periplasmic antiserum (Anti-44 kDa periplasmic). The first dimension isoelectric focusing (IEF) direction is shown. Samples were run in the second dimension on a $10 \%$ SDS-PAGE gel and either blotted for antibody probing or stained with Coomassie brilliant blue. 
(a)

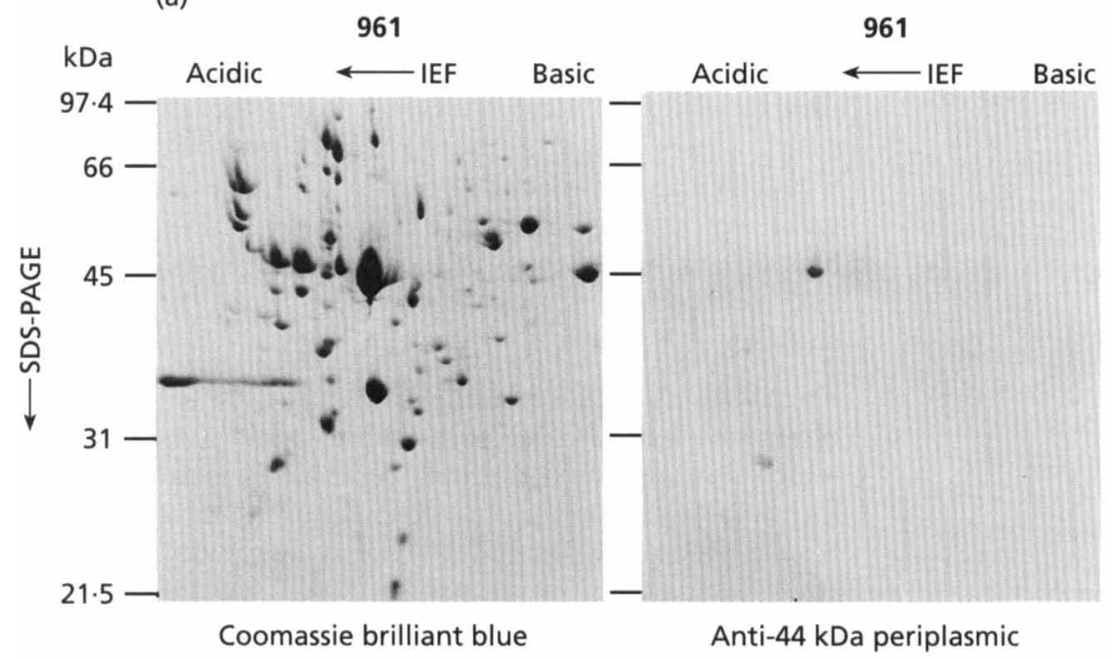

(b)

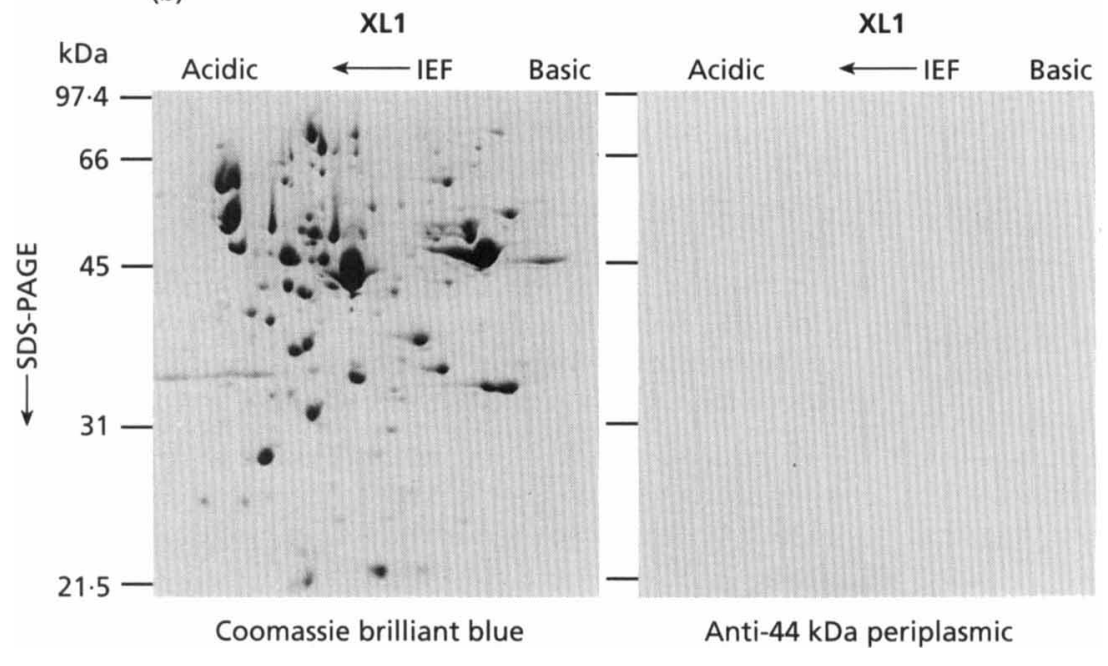

Fig. 2. Two-dimensional gel electrophoretic analysis of $E$. coli host strain XL1 and the 961 clone probed with $44 \mathrm{kDa}$ periplasmic antiserum. (a) 961 clone stained with Coomassie brilliant blue (CBB) and probed with $44 \mathrm{kDa}$ periplasmic antisera (Anti$44 \mathrm{kDa}$ periplasmic). (b) $E$. coli host strain XL1 stained with Coomassie brilliant blue and probed with $44 \mathrm{kDa}$ periplasmic antisera (Anti-44 kDa periplasmic). The first dimension isoelectric focusing (IEF) direction is shown. Samples were run in the second dimension on a $9 \%$ SDS-PAGE gel and either blotted for antibody probing, or stained with Coomassie brilliant blue. that the protein is expressed from an endogenous promoter element located in the cloned fragment and that expression was not solely the result of the lac promoter in the $\mathrm{pSK}$ - vector.

Of note, there are striking differences between the protein profiles for 961 and XL1 (Fig. 2a, b). This disparity in the protein profile may be evidence of a weakly growing $E$. coli recombinant. It is possible that the $44 \mathrm{kDa}$ protein is toxic to $E$. coli and that the 961 clone may contain a truncated insert or a cloning artifact which lowers the expression and/or toxicity of this gene.

\section{Sequence analysis of the 961 clone}

The gonococcal DNA fragment contained within the recombinant clone was sequenced in its entirety and this sequence is shown in Fig. 3 . The length of the sequenced fragment is 2439 bases. A partial ORF at the $5^{\prime}$ end of the DNA insert was found to encode a protein of calculated molecular mass $24.9 \mathrm{kDa}$. This protein was searched against the databases and found to be most homologous to E. coli EF-G (Blast score 282 , probability $4.1 \times 10^{-86}$ ). A Bestfit analysis showed this partial ORF to be $76.7 \%$ similar and $65.0 \%$ identical to E. coli EF-G. Therefore, based upon this high percentage of identity it is most likely that this partially cloned gene is a $N$. gonorrboeae $f u s A$ homologue. Immediately downstream of the fus $A$ homologue was a potential ribosome-binding site followed by a second ORF which codes for a protein of calculated molecular mass $43 \mathrm{kDa}$. This protein was searched against the databases and found to be highly homologous to $E$. coli FF-TuA (Blast score 1675, probability $4.7 \times 10^{-228}$ ). A Bestfit analysis of this protein compared to E. coli EF-TuA showed $90.6 \%$ similarity and $82.9 \%$ identity between the two proteins. A Bestfit analysis with $E$. coli EF-TuB showed $90 \cdot 3 \%$ similarity and $82.9 \%$ identity. Although it is not possible to differentiate whether or not the $N$. gonorrboeae EF-Tu protein is an EF-'TuA or EF-TuB homologue based upon these percentage identities or similarity scores, we believe that the presence of a fus $A$ gene immediately upstream and an rpsJ gene (discussed below) immediately down- 
(a)

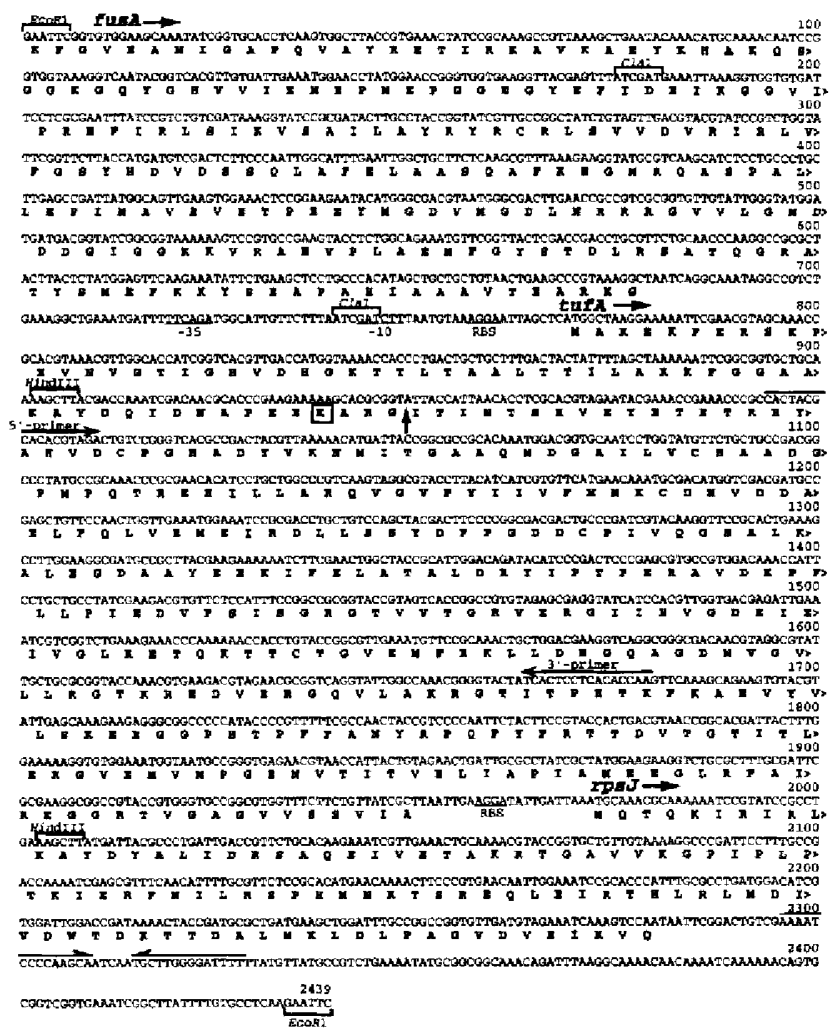

(b)

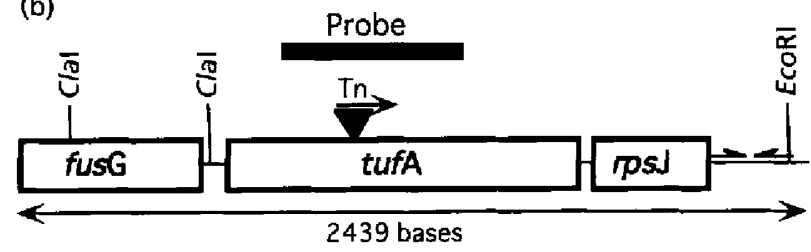

Fig. 3. Sequence of the $N$. gonorrhoeae DNA fragment contained within the pSP961 plasmid. (a) The length of the $N$. gonorrhoeae DNA fragment contained within the pSP961 plasmid is 2439 bases. Ribosome-binding sites and the potential promoter element for tufA are labelled and underlined as RBS and -10 and -35 , respectively. A large stem-loop, potential stop structure for the str operon is shown with inverted arrows. The lysine residue believed to be methylated is boxed and the potential cleavage site is shown with an arrow. Primers that were used to make the probe for Southern analysis are shown as line arrows with their respective primer names above. (b) A linkage map of the fusG, tufA and rpsJ genes based upon this PCR data and the sequence data.

stream of the EF-Tu ORF indicates that these genes constitute a portion of the str operon of the gonococcus. Therefore, based upon this str opeton homology, the EF$\mathrm{Tu}$ ORF is most likely encoded by tuf $A$. Immediately downstream of the $\operatorname{tuf} A$ homologue was a potential ribosome-binding site followed by a third ORF. This thitd ORF coded for a protein of calculated molecular mass $11.8 \mathrm{kDa}$. This protein was searched against the databases and found to be most homologous to E. coli $\$ 10$ (Blast score 365 , probability $1 \cdot 0 \times 10^{-45}$ ). A Bestfit analysis of this ORF compared with E. coli $\mathrm{S} 10$ showed $82.5 \%$ similarity and $68.9 \%$ identity between the two proteins. This high percentage of identity indicates that this ORF is most likely a gonoccocal rps J homologue.

During the double-stranded sequencing of this DNA insert, it was discovered that the putative start codon for the $\operatorname{tuf} A$ gene was an ATA codon. Oligonucleotide primers were made $5^{\prime}$ (5' GTTGAAG TGGAAAC'TCCG $\left.3^{\prime}\right)$ of the statt codon and $3^{\prime}\left(5^{\prime}\right.$ TTTACCATGGTCAACGTG 3) of the start codon and a 424 bp product was amplified by PCR from the chromosome of $N$. gonorrboede strain FA19 and MS11. These two PCR products were sequenced with the same PCR primers and it was determined, as shown in Fig. 3, that the start codon for tuf $A$ was actually ATG for these two strains. It is tempting to speculate that the mutation in the 961 clone may have been selected by enhanced $E$. coli survival, thus producing the ATA codon artifact.

To confirm the genetic linkage of $f u s G$, tuf $A$ and $r p s J$ genes, genomic DNA was isolated from $N$. gonorrboeae strain MS1 1 and FA19 and PCR reactions were performed on these templates with primers situated within the $3^{\prime}$ end of the fusG gene (5' G'T'TGAAG'TGGAAAC'TCCG 3') and a primer located downstream of the rpsj gene $\left(5^{\prime}\right.$ CAGCGCATCGGTAGTTTT 3'). A PCR product of $1.9 \mathrm{~kb}$, a size consistent with that predicted, was produced (data not shown). A linkage map of the $f u s G$, tuf $A$ and rpsJ genes based upon this PCR data and the sequence data is shown in Fig. 3(b).

The str operon in E. coli is composed of $r p s L, \operatorname{rps} G, f u s A$, and tuf $A$ (Jinks-Robertson \& Nomura, 1987). Downstream of the TAA stop codon for the rps J gene in the $N$. gonorrboeae cloned fragment are sequences suggestive of a transcriptional stop signal (Platt, 1986). This stop signal is composed of exact inverted repeats of 14 bp flanking 5 bases of non-homology as shown in Fig. 3. This structure suggests that this is the end of the str operon for $N$. gonorrboeae. The location of the rps J gene in the gonococcal str operon is in contrast to the str operon in E. coli; the significance of this finding is unclear.

Expression of the str operon in E. coli is controlled by a promoter in the rpsL gene which resides immediately upstream of $r p s G$ and $f u s A$. In $E$. coli, expression of $t u f A$ is higher than that of the other genes in the operon. This has been in part explained by the presence of several potential promoter elements in the terminal portion of fus A (Zengel et al., 1984). Promoter searches of the terminal region of the gonococcal fus $G$ gene and the intergenic region between $f u s G$ and $t u f A$ were performed using an algorithm based upon $E$. coli consensus promoter sequences (Mulligan et al., 1984). Only a single potential promoter was identified, upstream of the gonococcal tuf $A$ gene (Fig. 3), which has a sequence similarity score of $48 \%$ denoting a relatively weak promoter.

\section{Processing of the $\mathbf{N}$. gonorrhoeae EF-Tu protein}

To determine whether the $37 \mathrm{kDa}$ protein which reacted with the $44 \mathrm{kDa}$ periplasmic antiserum was in fact a truncated or a processed form of EF-Tu, antibody 

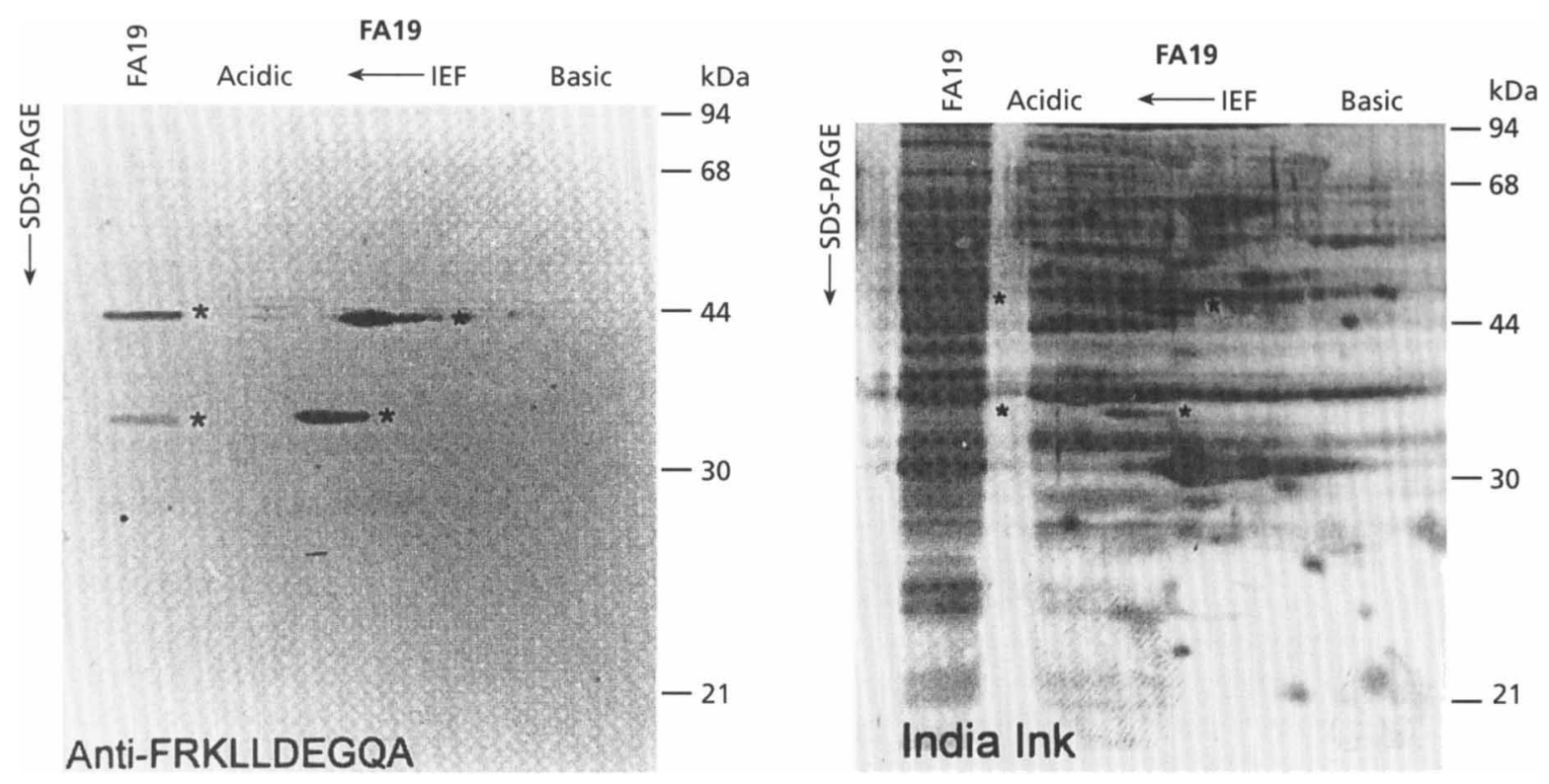

Fig. 4. One- and two-dimensional gel electrophoretic and immunoblot analysis of $N$. gonorrhoeae strain FA19 probed with an EF-Tu-specific antiserum. One- and two-dimensional gel electrophoretic analysis of $N$. gonorrhoeae strain FA19 immunoblotted with the peptide-specific EF-Tu antiserum (FRKLLDEGQA). The blot was subsequently stained with indian ink. The $44 \mathrm{kDa}$ and $37 \mathrm{kDa}$ proteins reactive with the anti-FRKLLDEGQA antisera and visualized with the India Ink are shown with asterisks.

previously generated against a portion of the gonococcal EF-Tu protein sequence (FRKLLDEGQA) known to be highly conserved amongst many EF-TuA and EF-TuB proteins (Judd \& Porcella, 1993) was used in immunoblots of one- and two-dimensional gels of $N$. gonorrboeae strain FA19 whole-cell lysates. This antiserum reacted with both the $44 \mathrm{kDa}$ and $37 \mathrm{kDa}$ proteins as shown in Fig. 4. The antiserum was immunoblotted against the 961 recombinant clone and only the $44 \mathrm{kDa}$ protein was detected (data not shown). These results suggest that the gonococcal EF-Tu protein is processed or cleaved to a smaller molecular mass form $(37 \mathrm{kDa})$ in $N$. gonorrboeae but not in the E. coli recombinant. Of note, previous use of this antiserum in one-dimensional immunoblots of $N$. gonorrboeae strain FA19 lysates detected the $37 \mathrm{kD}$ a protein in residue extracts while it failed to detect the $37 \mathrm{kDa}$ protein in whole-cell lysates (Judd \& Porcella, 1993). Where a less dilute mixture of the antiserum was used in previous studies a $37 \mathrm{kDa}$ protein was readily detected in whole cell lysates as shown in Fig. 4.

Evidence for a truncated or processed EF-Tu protein was recently described in a phage exclusion system in E. coli (Yu \& Snyder, 1994). The exclusion mechanism was due to a prophage encoded Lit protease specific for EF-Tu. Cleavage at a very specific and highly conserved sequence produced a $37 \mathrm{kDa}$ EF-Tu fragment which halted protein synthesis as a mechanism of immunity in the infected cell. The conserved site where endogenous cleavage has been demonstrated in E. coli (Yu \& Snyder, 1994) and predicted for $N$. gonorrboeae is at position 60 in the EF-TuA protein as shown in Fig. 3. The appearance of a lower molecular mass $\mathrm{EF}-\mathrm{Tu}$ protein in the gonococcus is the first example of EF-Tu cleavage in a bacterium other than e14containing E. coli $\mathrm{K}-12$ strains and has interesting implications with regatd to possible gonococcal phage exclusion mechanisms, gonococcal prophage elements, or an as yet undefined endogenous self-EF- $\mathrm{Tu}$ cleavage system. It is also important to note that no phage capable of infecting the gonococcus has ever been described.

EF-Tu appears to be influenced by nutrient availability and growth rate conditions, being methylated and bound to the cytoplasmic membrane during nutrient-limiting conditions (Young \& Bernlohr, 1991; Young et al., 1990). The putative methylation site described for E. coli and proposed for $N$. gonorrboeae is at Lys-57 in the EF-TuA protein sequence as shown in Fig. 3. EF-Tu concentrations, in terms of freely soluble ternary complexes, have been shown to directly affect growth and translation elongation rates (Tubulekas \& Hughes, 1993). A computer simulation of the $E$. coli translation system suggests that the concentration of EF-Tu should have a direct cause-and-effect relationship upon the dynamics and accuracy of protein synthesis (Pingoud et al., 1990). Therefore, self-cleavage of EF-Tu, with concomitant modulation of the rate of protein synthesis and/or the possible removal of the methylated portion of EF-Tu may have relevance to gonococcal survival and growth in diverse, nutrient-fluctuating environments.

\section{Attempted deletion of tufA}

A fragment of DNA containing the tuf $A$ gene was cut from the cloned insert in 961 using $\mathrm{ClaI}$ and EcoRI enzymes. This fragment was ligated into the pHSS6 


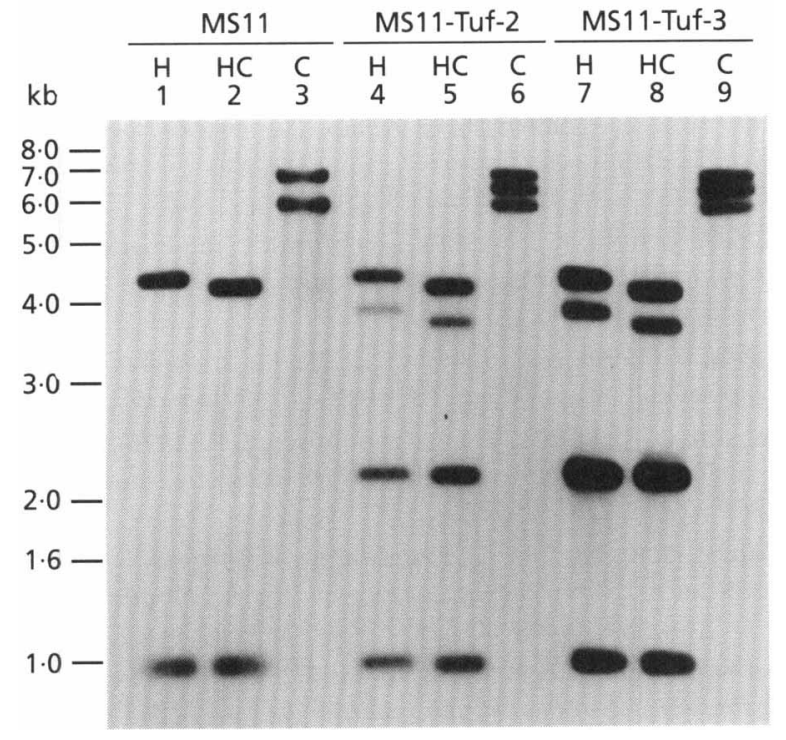

Fig. 5. Southern blot analysis of $N$. gonorrhoeae tufA mutants. Southern blot analysis was performed with MS11 genomic DNA (MS11), MS11 mutant transformant MS11-Tuf-2 genomic DNA and MS11-Tuf-3 genomic DNA digested with HindIII (H), HindIII + Clal $(\mathrm{HC})$, or Clal (C).

mutagenesis vector and mutagenized. The fragment containing the insertionally inactivated tuf $A$ gene was characterized by PCR using the oligos 3'TufA, 5'TufA and Cat. The defective chloramphenicol-containing transposon was located within the tuf $A$ gene in a $5^{\prime}$-to- $3^{\prime}$ orientation. The transposon resided approximately $0.6 \mathrm{~kb}$ from the $5^{\prime}$ end of the Clat $/ E c o R I$ fragment and $1.1 \mathrm{~kb}$ from the $3^{\prime}$ end of the fragment. The mutagenized DNA was obtained from the vector by digesting with NotI. After gel purification, the linear DNA fragment was transformed into pili-positive MS11 N. gonorrboeae and mutants resistant to chloramphenicol were selected. Twenty-four slow-growing, chloramphenicol-resistant mutants were identified. The plates were rechecked for mutants growing extremely slowly by longer incubation times, but no colonies were detected. From the 24 mutants, two were randomly seiected (designated MS11. Tuf- 2 and MS11-Tuf-3) and characterized by Southern blot analysis and PCR. The remaining 22 mutants were characterized solely by PCR. Southern blot analysis of the MS11-Tuf-2 and MS11-Tuf-3 mutants is shown in Fig. 5. The double-stranded probe used in the blot was constructed by PCR using primers internal to the $\operatorname{tuf} A$ gene $\left[\left(5^{\prime}\right.\right.$ primer (5' CACTACGCACACGTAGA 3'), 3' primer (5' TTGGTGTGAGGAGTGA 3')]. The locations of these primers are shown in Fig. 3. Southern analysis results in Fig. 5 show that the probe hybridized with both $\operatorname{tuf} A$ and another gene, presumably tuf $B$ (Goldstein et al., 1989). Based upon the presence of the HindIII sites in the cloned fragment, as shown in Fig. 3, we believe that the $1 \mathrm{~kb}$ fragment hybridizing in the

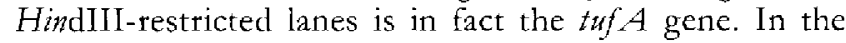
lanes marked MS11-Tuf-2 and MS11-Tuf-3 a further hybridizing fragment(s) is present while the wild-type hybridizing fragments are unchanged. The transposon within the mutated tuf $A$ allele contains a HindIII site that would produce a hybridizing fragment of approximately $2.3 \mathrm{~kb}$. 'This $2.3 \mathrm{~kb}$ hybridizing fragment can be seen in Fig. 5. The HindIII fragments seen at approximately $3.8-4.0 \mathrm{~kb}$ are probably the result of an unknown HindIII site located in the genome adjacent to the mutated allele. If a homologous recombination event had taken place between the transforming DNA and the $t u f A$ locus a shift or loss of the $1 \mathrm{~kb}$ band in the MS11-Tuf-2-and/or MS11Tuf-3-digested DNA would have been seen in the Southern analysis. Instead, it appears that a duplication has occurred following transformation of MS11 with the mutated tuf $A$ gene. It is possible that the transposonmutagenized fragment recombined with the smaller ClaI fragment resulting in a lethal event and autolysis. Transformation of a neighbouring cell by this region of the chromosome would result in a duplication of this area in the transformant. This type of result has been described previously (Taha et al., 1988) for the pill $A$ gene of $N$. gonorrhoeae. Southern analysis data indicate that the two tuf $A$ mutants isolated are heterodiploids in that they have gained the chloramphenicol-resistance-conferring fragment while maintaining the integrity of the genomic copies of the tuf $A$ and tuf $B$ genes.

PCR analysis using the $3^{\prime}$ TufA, $5^{\prime \prime} T$ uf $A$ and Cat primers was performed on the MS11-Tuf-2 and MS11-Tuf-3 mutants. These data are not shown but are summarized as follows. PCR was first performed using the primers $3^{\prime}$ TufA and 5'TufA on the transforming DNA and was shown to produce a fragment of $3 \mathrm{~kb}$; consistent with the size predicted for the transposon-containing fragment. PCR analysis with the same primers performed on the wild-type MS11 DNA produced a $1.5 \mathrm{~kb}$ fragment; consistent with the expected size for this portion of the str operon. PCR analysis of the wild-type DNA and the transforming DNA with the 5'TufA and Cat primer produced no INA fragment in the wild-type and a fragment of $2.0 \mathrm{~kb}$ (consistent with the location of the transposon) for the transforming DNA. Genomic DNA was isolated from the two mutants and PCR, using the $5^{\prime \prime}$ TufA and $3^{\prime}$ TufA primers, produced a $1.5 \mathrm{~kb}$ fragment for each mutant, thereby indicating that an intact copy of the tuf $A$ gene still existed. PCR analysis with the $5^{\prime}$ Tuf $A$ and Cat primer produced a fragment of $2 \mathrm{~kb}$ in the two mutants indicating that the transforming DNA was located in the chromosome in an unknown location. This PCR analysis confirmed the Southern blot data in that presumably functional copies of the $\operatorname{tuf} A$ gene were still intact while the transforming DNA was present but located in an unknown region of the chromosome.

It is generally believed that the $1 \%$ nucleotide difference that exists between the tuf $A$ and tuf $B$ genes in E. coli and $S$. typhimurium is sufficient to prevent high levels of homologous recombination between the genes. Given this premise and the fact that roughly $1.7 \mathrm{~kb}$ of str operonspecific DNA flanked the transposon we believed that the odds of recombination occurring at the $t u f B$ locus were minimal. Given that our primary interest was in the deletion of the $\operatorname{tuf} . A$ gene, we decided to characterize the 
remaining 22 mutants by $\mathrm{PCR}$ analysis alone using the $3^{\prime}$ TufA, 5'TufA and Cat primers. Unfortunately, all of the remaining 22 mutants produced PCR profiles identical to those previously described for MS11-Tuf-2 and MS11Tuf-3. Therefore, we were unable to functionally delete the tuf $A$ gene of $N$. gonorrhoeae.

The $t u f B$ gene of $E$. coli has been inactivated by insertion of a Mu phage genome (van de Klundert et al., 1978; Young \& Furano, 1981) while the $\operatorname{tuf} A$ gene has been shown to be essential (Vijgenboom \& Bosch, 1987). It is possible that in our mutagenesis procedures a potential polar effect upon the rpsJ gene may have occurred. Given the unusual location of the $r p s /$ gene in the $N$. gonorrboeae str operon (as compared to the location of this gene in $E$. coli) we do not know whether this gene is essential in this context.

The presence of heterodiploids arising during the mutagenesis of a potentially essential gene such as tuf $A$ is similar to the phenomenon observed with the pil $A$ gene, a gene thought to be essential in N. gonorrboeae (Taha et al., 1988). These results are consistent with the notion that the tuf $A$ gene of $N$. gonorrboeae is essential.

\section{ACKNOWLEDGEMENTS}

We are extremely grateful to Dr John Swanson for his generous support, scientific advice and encouragement. Special thanks goes to Sandra Morrison for all her help and expert technical assistance. We also thank Joan Strange of the University of Montana Murdock Molecular Biology Facility for her superb sequencing efforts. This work was supported by PHS grant RO1 A121236, UM grant 1117, the Murdock Charitable Trust, and the laboratory of Microbial Structure and Function, RML, NIAID, NIH, Hamilton MT.

\section{REFERENCES}

Arai, K., Clark, B. F. C., Duffy, L., Jones, M. D., Kaziro, Y., Laursen, R. A., L'Italien, J., Miller, D. L., Nagarkatti, S., Nakamura, S., Nielsen, K. M., Petersen, T. E., Takahashi, K. \& Wade, M. (1980). Primary structure of elongation factor Tu from Eschericbia coli. Proc Natl Acad Sci USA 77, 1326-1330.

Chen, C. Y., Parsons, C. S. \& Morse, S. A. (1984). Membrane proteolipids of Neisseria gonorrhoeae. In The Pathogenic Neisseriae, pp. 360-365. Edited by G. K. Schoolnik, Washington, DC: American Society for Microbiology.

Cohen, D. M. (1990). Southern blotting and hybridization. In Current Protocols in Molecular Biology, pp. 2.9.1-2.9.17. Edited by F. M. Ausubel. New York, NY: John Wiley.

Devereux, J., Haeberli, P. \& Smithies, O. (1984). A comprehensive set of sequence analysis programs for the VAX. Nucl Acids Res 12, 387-395.

Goldstein, B. P., Zaffaroni, G., Tiboni, O., Amiri, B. \& Denaro, M. (1989). Determination of the number of tuf genes in Chlamydia trachomatis and Neisseria gonorrboeae. FEMS Microbiol Lett 60, 305-310.

Goodman, S. D. \& Scocca, J. J. (1991). Factors influencing the specific interaction of Neisseria gonorrhoeae with transforming DNA. J Bacteriol 173, 5921-5923.
Hill, S. A. \& Judd, R. C. (1988). Structural and immunological characterization of cell wall antigens in strains FA638 and CS7 of Neisseria gonorrboeae. In Gonococi and Meningococci. pp. 373-381. Edited by J. T. Poolman, H. C. Zanen, T. F. Meyer, J. E. Heckels, P. R. H. Makela, H. Smith \& E. C. Beuvery. Dordrecht, The Netherlands: Kluwer Academic Publishers.

Hill, S. A. \& Judd, R. C. (1989). Identification and characterization of peptidoglycan-associated proteins in Neisseria gonorrboeae. Infect Immun 57, 3612-3618.

Hughes, D. (1990). Both genes for EF-Tu in Salmonella typhimurium are individually dispensable for growth. $J$ Mol Biol 215, 41-51.

Jacobson, G. R.، Takacs, B. J. \& Rosenbusch, J. P. (1976). Properties of a major protein released from Escherichia coli by osmotic shock. Biocbemistry 15, 2297-2302.

Jaskunas, S. R., Lindahl, L., Nomura, M. \& Burgess, R. R. (1975). Identification of two copies of the gene for the elongation factor EF-Tu in E. coli. Nature 257, 458-462.

Jinks-Robertson, S. \& Nomura, M. (1987). Ribosomes and tRNA. In Escherichia coli and Salmonella typhimurium, pp. 1358-1385. Edited by F.C. Neidhardt. Washington, DC: American Society for Microbiology.

Jones, M. D., Petersen, T. E., Nielsen, K. M., Magnusson, S., Sottrup-Jensen, L., Gausing, K. \& Clark, B. F. C. (1980). The complete amino-acid sequence of elongation factor $\mathrm{Tu}$ from Escherichia coli. Euro J Biochem 108, 507-526.

Judd, R. C. (1982). ${ }^{125}$ I-peptide mapping of protein III isolated from four strains of Neisseria gonorrboae. Infect Immun 37, 622-631.

Judd, R. C. (1988). Purification of outer membrane proteins of the gram-negative bacterium Neisseria gonorrboeae. Anal Biochem 173, 307-316.

Judd, R. C. (1991). Identification and characterization of conserved outer membrane proteins of Neisseria gonorrboea. In Proceedings of the Seventh International Conference on Pathogenic Neisseria, pp. 247-252. Edited by M. Achtman. Berlin, Germany: Walter de Gruyter.

Judd, R. C. \& Porcella, S. F. (1993). Isolation of the periplasm of Neisseria gonortboeae. Mol Microbiol 10, 567-574.

Judd, R. C., Strange, J. C., Pettit, R. K. \& Shafer, W. M. (1991). Identification and characterization of a conserved OMP of Neisseria gonorrboeae. Mol Microbiol 5, 1091-1096.

Laemmli, U. K. (1970). Cleavage of structural proteins during the assembly of the head of bacteriophage T4. Nature 227, 680-685.

Maniatis, T., Fritsch, E. F. \& Sambrook, J. (1982). Molecular Cloning: a Laboratory Manual. Cold Spring Harbor, NY: Cold Spring Harbor Laboratory.

Mulligan, M. E., Hawley, D. K., Entriken, R. \& McClure, W. R. (1984). Escherichia coli promoter sequences predict in vitro RNA polymerase selectivity. Nul Acids Res 12, 789-800.

O'Farrell, P. H. (1975). High resolution two-dimensional electrophoresis of proteins. I Biol Chem 250, 4007-4021.

Pingoud, A., Gast, F. \& Peters, F. (1990). The influence of the concentrations of elongation factors and tRNAs on the dynamics and accuracy of protein biosynthesis. Biocbim Biopbys Acta 1050, 252-258.

Platt, T. (1986). Transcription termination and the regulation of gene expression. Ann Rev Biocbem 55, 339-372.

Porcella, S. F. \& Judd, R. C. (1993). Polyclonal antibody characterization of the conserved outer membrane protein of Neisseria gonorboeae and Neisseria meningitidis. In Patbobiology and Immunobiology of Neisseriaceae, pp. 568-574. Edited by C. J. Conde-Glez. Cuernavaca, Mexico: Instituto National de Salud Publica.

Sambrook, J., Fritsch, E. F. \& Maniatis, T. (1989). Molecular Cloning: 
a Laboratory Manzal, 2nd edn. Cold Spring Harbor, NY: Cold Spring Harbor Laboratory.

Sanger, F., Nicklen, S. \& Coulson, A. R. (1977). DNA sequencing with chain-terminating inhibitors. Proc Natl Acad Si USA 74, 5463-5467.

Seifert, H. S. \& So, M. (1991). Genetic systems in pathogenic Neisseria. Methods in Enzymology 204, 342-357.

Seifert, H. S., Ajioka, R. S., Paruchuri, D., Heffron, F. \& So, M. (1990). Shuttle mutagenesis of Neisseria gonorrhoeae: Pilin null mutations lower DNA transformation competence. $J$ Bacteriol 172, $40-46$.

Seifert, H. S., Chen, E. Y., So, M. \& Heffron, F. (1986). Shuttle Mutagenesis: a method of transposon mutagenesis for Saccharomyces cerevisiat. Proc Natl Acad Sci US A 83, 2177-2181.

Shafer, W. M. (1988). Lipopolysaccharide masking of gonococcal outer-membrane proteins modulates binding of bactericidal cathepsin G to gonococci. J Gen Microbiol 134, 539-545.

Shafer, W. M. \& Judd, R. C. (1991). Gonococcal PBP-3 and the surface-exposed PG-binding protein of Neisseria gonorrboeae appear to be the same molecule. Mol Microbiol 5, 1097-1103.

Shafer, W. M. \& Morse, S. A. (1987). Cleavage of the protein III and major iron-regulated protein of Neisseria gonorrboeae by lysosomal cathepsin G. J Gen Mirrobiol 133, 155-162.

Swanson, J. (1981). Surface-exposed protein antigens of the gonococcal outer membrane. Infect Immun 34, 804-816.

Swanson, J. (1982). Colony opacity and protein II compositions of gonococci. Infect Immun 37, 359-368.

Taha, M. K., So, M., Seifert, H. S., Billyard, E. \& Marchal, C. (1988). Pilin expression in Neisseria gonorrboeae is under both positive and negative transcriptional control. EMBO J 7, 4367-4378.

Tubulekas, I. \& Hughes, D. (1993). Growth and translation elongation rate are sensitive to the concentration of EF-Tu. $\mathrm{Mol}$ Microbiol 8, 761-770. van de Klundert, J. A. M., van der Meide, P. H., van de Putte, P. \& Bosch, L. (1978). Mutants of Eschericbia coli altered in both genes coding for the elongation factor Tu. Proc Natl Acad Sci USA 75, 4470.4473 .

Van der Meide, P. H., Vijgenboom, E., Dicke, M. \& Bosch, L. (1982). Regulation of the expression of tuf $A$ and $t u f B$, the two genes coding for the elongation factor EF.'Tu in Escherichia coli. FEBS Letters 139, 325-330.

Vijgenboom, E. \& Bosch, L. (1987). Transfer of plasmid-borne tuf mutations to the chromosome as a genetic tool for studying the functioning of EF-TuA and EF-TuB in the E. coli cell. Biacbimie 69 , $1021-1030$.

Young, C. C. \& Bernlohr, R. W. (1991). Elongation factor Tu is methylated in response to nutrient deprivation in Escbericbia coli. I Bacteriol 173, 3096-3100.

Young, F. S. \& Furano, A. V. (1981). Regulation of the synthesis of Eschericbia coli elongation factor Tu. Cell 24, 695-706.

Young, C. C., Alvarez, J. D. \& Bernlohr, R. W. (1990). Nutrientdependent methylation of a membrane-associated protein of Escherichia coli. J Bacteriol 172, 5147-5153.

Yu, Y. T. N. \& Snyder, L. (1994). Translation elongation factor Tu cleaved by a phage-exclusion system. Proc Natl Acad Si US A 91, 802-806.

Zak, K., Diaz, J. L., Jackson, D. \& Heckels, J. E. (1984). Antigenic variation during infection with Neisseria gonorthoeae: detection of antibodies to surface proteins in seta of patients with gonorrhoea. J Infect Dis 149, 166-174.

Zengel, J. M., Archer, R. H. \& Lindahl, L. (1984). The nucleotide sequence of the Escheribia colifws gene, coding for elongation factor G. Nuct Acids Res 12, 2181-2192.

Received 21 March 1996; revised 16 May 1996; accepted 23 May 1996. 